
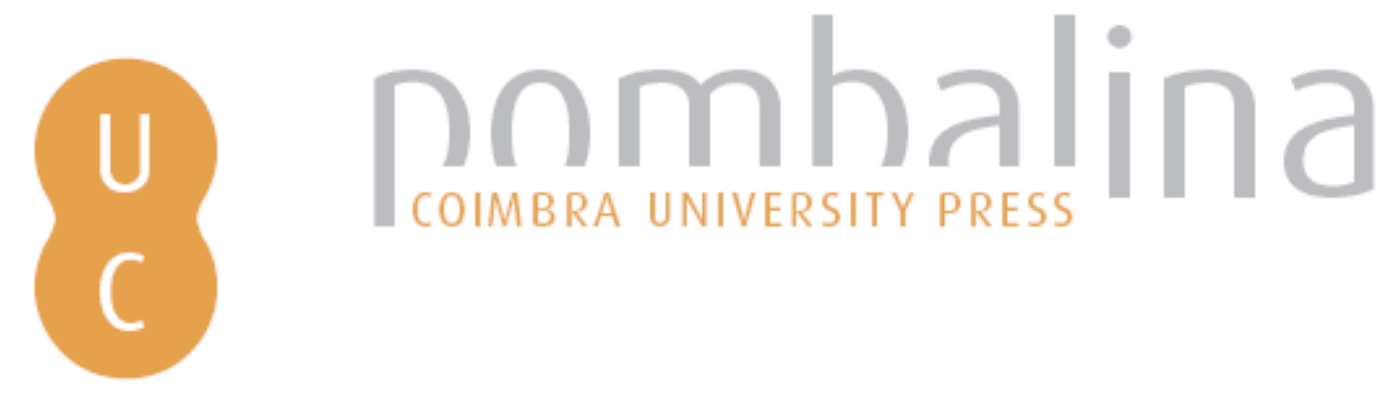

\title{
O papel das redes sociais nas políticas sociais: o caso da rede nacional de cuidados continuados integrados
}
Autor(es):
Hespanha, Maria José; Hespanha, Pedro
Publicado por: Imprensa da Universidade de Coimbra
URL
persistente:
URI:http://hdl.handle.net/10316.2/31326
DOI:
DOI:http://dx.doi.org/10.14195/978-989-26-0222-6_7
Accessed : $\quad$ 26-Apr-2023 03:55:02

A navegação consulta e descarregamento dos títulos inseridos nas Bibliotecas Digitais UC Digitalis, UC Pombalina e UC Impactum, pressupõem a aceitação plena e sem reservas dos Termos e Condições de Uso destas Bibliotecas Digitais, disponíveis em https://digitalis.uc.pt/pt-pt/termos.

Conforme exposto nos referidos Termos e Condições de Uso, o descarregamento de títulos de acesso restrito requer uma licença válida de autorização devendo o utilizador aceder ao(s) documento(s) a partir de um endereço de IP da instituição detentora da supramencionada licença.

Ao utilizador é apenas permitido o descarregamento para uso pessoal, pelo que o emprego do(s) título(s) descarregado(s) para outro fim, designadamente comercial, carece de autorização do respetivo autor ou editor da obra.

Na medida em que todas as obras da UC Digitalis se encontram protegidas pelo Código do Direito de Autor e Direitos Conexos e demais legislação aplicável, toda a cópia, parcial ou total, deste documento, nos casos em que é legalmente admitida, deverá conter ou fazer-se acompanhar por este aviso.

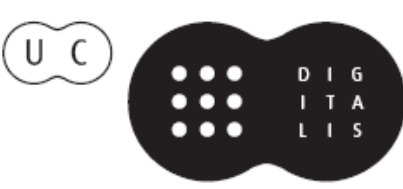


Sílvia Portugal

Paulo Henrique Martins

Organização

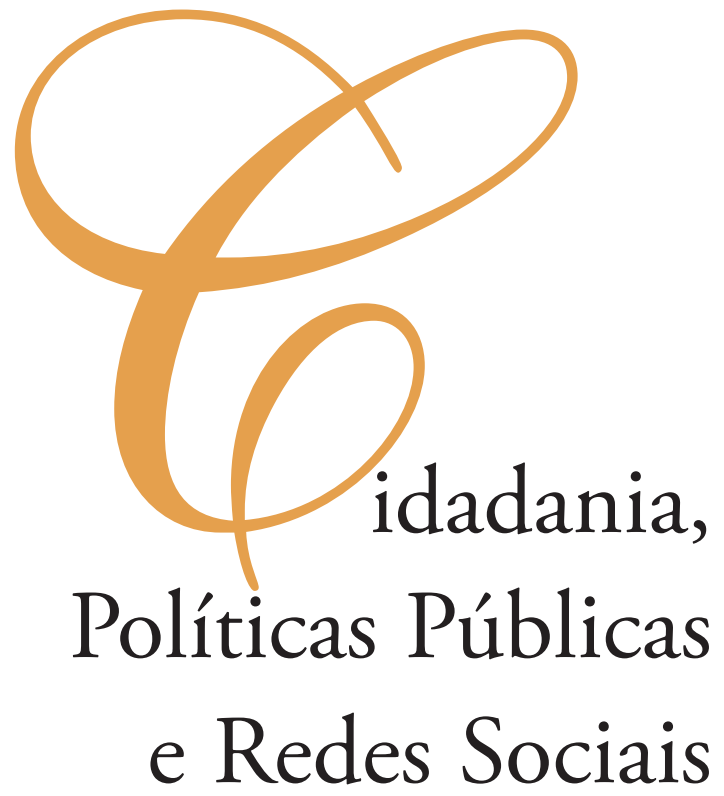


Maria José Hespanha e Pedro Hespanha

\section{O PAPEL DAS REDES SOCIAIS NAS POLÍTICAS SOCIAIS. O caso da Rede Nacional de Cuidados Continuados Integrados}

\section{Introduçáo}

Nos últimos anos, temos vindo a assistir a uma crescente preocupação dos sucessivos governos com a escassez da oferta de cuidados continuados para as pessoas dependentes e a tentativas sucessivas de encontrar respostas eficazes para estas pessoas.

Todos sabemos que as condiçóes para ajudar as pessoas dependentes, na sua grande maioria idosos, têm vindo a piorar, não só porque as condições de trabalho dos familiares levam a uma crescente indisponibilidade de tempo, mas ainda devido a razóes mais gerais que têm a ver com os novos regimes demográficos. Assim, ao aumento da população idosa acresce a redução da população que pode prestar apoio, em virtude da conjugaçáo de uma série de factores, dentre os quais o declínio da taxa de natalidade, o retardamento da idade de procriação, o aumento do divórcio e das famílias monoparentais, o aumento da participação da mulher no mercado de trabalho, etc.

O problema principal é que as famílias contemporâneas não têm condiçôes para cuidar dos seus dependentes, assim como dificilmente conseguem assumir o acompanhamento dos seus idosos e que, para além da família, poucas são as instituiçóes capazes de assegurar os cuidados de que esta população necessita. A acrescentar a este problema encontra-se o facto da maioria dos idosos serem pobres e não terem possibilidade de proverem todos os cuidados de que necessitam no seu quotidiano. A taxa de pobreza dos idosos em Portugal em 2005 - 28\% é bem mais elevada que a média - 20\% (UE15 - 20\%) (EUROSTAT, 2007).

O acompanhamento dos idosos e dos dependentes tem estado a cargo dos sistemas de saúde e de segurança social, mediante intervençóes parcelares e respostas imediatas para problemas complexos de sobrevivência.

O sistema de saúde, durante muitas décadas estruturado num modelo hospitalocentrico onde a dimensão "caso clínico" era mais importante do que a dimensão "pessoa", teve de se adaptar ao surgimento dos cuidados de saúde primários e à necessidade de integrar a perspectiva bio-psico-social da doença que estes seguem e começa agora a conviver com uma nova realidade: a procura de soluçóes por parte de uma população muito idosa que entra nos hospitais, ocupa camas, sobrecarrega os profissionais devido aos níveis de dependência que apresenta e sem grande hipótese de sucesso terapêutico. Neste quadro, pede-se ao sistema de saúde que dê uma resposta que respeite, simultaneamente, a necessidade de prestar cuidados de qualidade e especializados a esta população, de criar instituições ade- 
quadas a prestar esses cuidados por forma a reservar os hospitais para episódios de doença aguda, de aliviar as famílias do encargo pesado de cuidar dos seus familiares dependentes de cuidados continuados e relativamente especializados e de integrar as ajudas que o sector social presta aos doentes e suas famílias.

Essa resposta consiste nos cuidados continuados e tem vindo, em muitos países, a tornar-se uma área central dos cuidados de saúde. Em Portugal é o Programa Rede Nacional de Cuidados Continuados Integrados (RNCCI), recentemente criado na sequência de outras medidas menos estruturadas, que dá corpo a esta nova área de intervenção.

Existe, porém, a nível internacional uma grande ambiguidade na delimitação desta área dos cuidados e uma grande diversidade de modelos de intervenção, com diferente participação da esfera pública, das organizaçôes da sociedadee civil e das famílias.

O objectivo deste texto é, a partir da noção de rede social, analisar as formas institucionais e não institucionais de prestação de cuidados continuados e reflectir, para o caso português, sobre o sentido de algumas opçóes tomadas na construção do modelo de prestação de cuidados (RNCCI) quer quanto ao desenho da rede institucional, quer quanto ao reconhecimento das redes informais de cuidados.

Começaremos por abordar a questão da ambiguidade conceptual que rodeia este tipo de cuidados e discutir os diferentes objectivos visados pelas políticas que os pretendem desenvolver, nem sempre coerentes entre si e dominados por preocupaçóes diversas. A seguir será valorizada a questáo dos modelos prevalecentes na protecção social e, designadamente, a do papel e responsabilidade atribuídos ao Estado neste domínio mais específico dos cuidados continuados de saúde e de bem-estar social. Finalmente será apresentado o programa da Rede de Cuidados Continuados e Integrados, discutindo, a propósito, as implicaçóes que decorrem do modelo escolhido em Portugal - uma rede institucional de serviços e equipamentos à escala nacional e uma rede de parceiros cooperando de uma forma articulada e integrada à escala local - para a sua concretização prática, tendo em conta as necessidades e as expectativas dos cidadãos, dos profissionais e das Instituiçóes.

\section{Um campo de limites imprecisos}

Uma pesquisa sobre as designaçôes usadas nos diferentes países para os cuidados continuados revela a diversidade das designaçóes e a imprecisão dos seus limites. Em parte explicada pela história da intervenção em cada país, a diversidade tem ainda a ver com a natureza e configuração dos sistemas de protecção social e também com as orientaçóes ditadas pelas organizaçôes internacionais ${ }^{1}$.

Dentre as designações mais usadas quer pelos Estados quer pelas organizaçôes internacionais, contam-se as de "cuidados continuados" (continuing care), "cuidados de longa duração" (long-term care) e "cuidados integrados" (integrated care), cada uma delas reflectindo objectivos que, nas situaçóes reais, se encontram quase sempre sobrepostos.

Sem menosprezar a dificuldade das definiçóes, poder-se-ia caracterizar, de uma forma sintética, os três tipos de cuidados nos seguintes termos.

\footnotetext{
1 Mais recentemente organizaçóes internacionais como a OMS, a OCDE e a Uniăo Europeia têm vindo também a ocupar-se do tema e, por essa via, a fixarem terminologias e conteúdos de acçáo.
} 
Os cuidados continuados visam apoiar pessoas com necessidades que se prolongam por uma duração que não sendo necessariamente longa exigem um acompanhamento ao longo de um certo tempo. Na definição do Instituto de Medicina de Washington eles consistem "numa variedade de serviços continuados de saúde e sociais, prestados a indivíduos que precisam de assistência numa base continuada em virtude de um problema físico ou psicológico. Os serviços podem ser prestados numa instituição, no domicílio ou em centros comunitários". Cabem nesta designação as situaçôes mais diversas. Categorias de pessoas como idosos, pessoas com deficiência física ou mental, todas elas caracterizadas por necessitarem de cuidados regulares. Os cuidados continuados consistem num conjunto de serviços e processos de cuidar orientados para pessoas com necessidades semelhantes. Esses serviços tanto podem consistir em cuidados domiciliários de enfermagem ou saúde e acompanhamento social, como em alojamento, transporte, fornecimento de refeiçóes ou actividades ocupacionais, podendo exigir ou não qualificaçóes técnicas elevadas e pertencer ao domínio dos cuidados de saúde ou dos cuidados sociais.

A dificuldade em comparar este tipo de cuidados de país para país pode ser explicada por muitos factores: a) os serviços estão frequentemente dispersos por diferentes organismos públicos e privados; b) o sistema de cuidados é muito influenciado pela existência ou não de uma cultura de cuidados informais ou familiares como acontece nos países do sul da Europa; c) estes sistemas têm estado a ser objecto de reformas ou de expansão com contornos muito diferenciados; d) o papel dos cuidados de saúde relativamente aos de outras instituiçôes como os serviços sociais varia muito de país para país; e) finalmente os sistemas de cuidados assumem configuraçóes muito distintas conforme o modelo de protecção social que vigore num país (modelo universalista, financiado por impostos; modelo corporativo financiado pelas contribuiçôes de seguro obrigatório; modelo liberal de escasso financiamento público) ou combinam vários modelos de protecção social.

Os cuidados de longa duração não se distinguem claramente dos anteriores e, com frequência, se usa esta designação para as acçóes que configuram os cuidados continuados. Acresce que esta designação está a ser cada vez mais usada pelas organizaçóes internacionais (OECD, 2005). A característica mais marcante é o facto de os cuidados de longa duração se dirigirem a situaçôes de dependência prolongada no tempo e não a situaçóes de dependência esporádica e facilmente resolúvel no quadro das respostas hospitalares ou comunitárias existentes. Porém, o que conta mais é o carácter agudo ou dificilmente gerível da situação de dependência pela família, mesmo quando a duração expectável da dependência não seja muito longa. Do ponto de vista dos conteúdos, é frequente estes cuidados compreenderem cuidados náo especializados de vigilância e acompanhamento de tarefas diárias da pessoa dependente (como vestir-se, tomar banho ou serviços de higiene), para além de cuidados médicos e de enfermagem.

Os cuidados integrados visam prestar serviços adequados à muitidimensionalidade dos problemas da populaçáo alvo dos cuidados, nomeadamente a população idosa e dependente, ou seja, integrar as respostas médicas, sociais ou outras nos serviços prestados. Sabe-se como o envelhecimento da população está a tornar cada vez mais complexa e diversificada a resposta dos serviços, em grande parte porque persiste uma oferta fragmentada e dispersa desses serviços. Este objectivo tem-se revelado difícil de atingir particularmente nos países em que os cuidados sociais e os cuidados de saúde pertencem a ministérios distintos. Nestes casos o desafio consiste em gerar arranjos inter institucionais (por meio de protocolos ou de equipas multidisciplinares), em garantir compromissos entre as instituiçóes (pelo reforço 
da confiança mútua e da cooperação) e em explorar as boas práticas (através de um processo contínuo de aprendizagem e avaliação) (Van Raak et al. 2003). Também as relações entre parceiros públicos e parceiros privados depende de um quadro claro de regulação entre ambos e de um clima de confiança recíproca no respeito da autonomia e da missão de cada parceiro.

O facto de a estrutura de cuidados de saúde para problemas relacionados com o envelhecimento e a dependência se ter modificado no sentido de uma reduçáo do envolvimento hospitalar - redução do número de camas hospitalares, redução da permanência média em internamentos hospitalares - pode levar ainda, e tem levado, a uma maior procura de cuidados primários de saúde (UEMO, 2002) e da própria medicina interna, duas especialidades de cuidados médicos muito próximas daquelas de que nos ocupamos.

No contexto europeu (particularmente relevante para a análise do caso português) os cuidados continuados têm sido objecto de tratamento privilegiado, desde, pelo menos o Conselho Europeu de Lisboa de Março de 2000 que assinalou a necessidade de reformar os sistemas de protecçáo social. Em Dezembro de 2001 uma Comunicaçáo da Comissão Europeia "O Futuro da Assistência de Saúde e dos Cuidados às Pessoas Idosas: Garantir a Acessibilidade, a Qualidade e a Sustentabilidade Financeira” veio desafiar os sistemas de assistência de saúde e os cuidados de longa duração a garantir o acesso universal independentemente dos rendimentos e dos bens pessoais, um alto nível na qualidade da assistência e a respectiva sustentabilidade financeira. Reconhecia-se que estes objectivos dependiam da taxa de envelhecimento da população e das evoluçôes sociais e tecnológicas, referindo entre estas: as novas tecnologias e terapêuticas, a melhoria do bem estar e da informação ao doente e o envelhecimento da populaçáo (necessidade de promover um envelhecimento activo).

A Comunicação da Comissão Europeia "Modernizar a Protecção Social para o Desenvolvimento de Cuidados de Saúde e de Longa Duração com Elevada Qualidade, Acessíveis e Sustentáveis: Apoio às Estratégias Nacionais Usando o Método Aberto de Coordenação" reconhece que a protecção social é um meio de distribuir, ao nível da sociedade no seu todo, os custos que muitas vezes excedem os recursos de um indivíduo ou de uma família, garantindo que o pagamento dos cuidados de saúde náo conduza ao seu empobrecimento e que mesmo aqueles que tenham rendimentos mais baixos possam aceder aos cuidados. Para além disso reconhece a necessidade de "envolver e atribuir responsabilidades a todos os actores que participam no sistema de cuidados - incluindo parceiros sociais, as autoridades regionais e locais, os doentes e a sociedade civil - e coordenar os prestadores de cuidados, as organizaçôes financeiras, as ONG`s e as autoridades públicas” (EC, 2004). Tendo isto em conta a Comunicação propóe uma série de objectivos conjuntos a satisfazer pelos Estados Membros dentre os quais se incluem os seguintes:

- oferecer a toda a população cuidados de elevada qualidade adaptados às suas necessidades

- oferecer cuidados específicos para a população idosa baseados numa coordenaçáo entre os serviços sociais, os prestadores de cuidados primários, os serviços hospitalares e as instituições especializadas;

- promover cuidados paliativos e terminais

- reduzir, onde necessário, as desigualdades regionais na prestação de cuidados;

- desenvolver, onde necessário, estruturas adequadas com pessoal treinado para aumentar a oferta de cuidados e reduzir as listas de espera;

- promover cuidados de elevada qualidade para melhorar o estado de saúde das pessoas e a qualidade de vida; 
- assegurar um nível elevado de formação básica e contínua dos trabalhadores dos cuidados de saúde;

- definir os direitos dos doentes e das suas famílias e os modos de participação da sociedade civil organizada;

- assegurar a existência de fundos públicos suficientes e a sua disponibilidade para satisfazer as necessidades do sistema de cuidados;

- melhorar a eficácia do sistema, baseado na descentralização, através do envolvimento dos vários actores (autoridades públicas locais e regionais, instituiçóes da segurança social e outros financiadores, os profissionais de saúde e hospitais e os doentes), tornando-os responsáveis pela gestáo dos recursos e pela prestação dos cuidados (EC 2004).

Em síntese, existe hoje por parte das instituiçóes da União Europeia uma clara prioridade atribuída aos cuidados continuados e um esforço para envolver os Estados Membros na construção de sistemas de cuidados de acesso universal equitativos e solidários. E, de acordo com o que se expressa no ponto imediatamente anterior, o modelo de gestão preferido não é mais o da provisão pública exclusiva mas sim o de uma gestão em parceria envolvendo instituiçóes públicas e privadas, profissionais e famílias. Fica aberto, em cada Estado, a configuração específica que assume este modelo e, particularmente, a extensão dos poderes conferidos a cada um dos actores nessa parceria.

\section{Uma diversidade de sistemas. As tipologias de welfare}

A configuração nacional dos modelos não é um produto da livre escolha, antes depende, em grande medida, da própria filosofia e história do sistema de protecção social. É que os Estados Membros têm regimes de protecção muito distintos no que respeita à responsabilidade do Estado na intervenção, no que respeita os modos de financiar as políticas sociais, no que respeita ao universo das pessoas abrangidas pela protecção e no que respeita aos níveis de protecção.

Quanto ao primeiro aspecto, a responsabilidade do Estado nas respostas sociais, os regimes de protecção variam entre uma filosofia mais liberal em que a satisfação das necessidades (e, designadamente, as sociais) é considerada um assunto dos indivíduos e das famílias e o Estado só intervém quando eles sejam de todo incapazes de assegurar as respostas às suas necessidades pelos próprios meios e uma filosofia mais social-democrática em que o Estado reconhece como missão sua assegurar que todos os cidadãos possam fruir gratuitamente de um certo nível de satisfação das necessidades sociais ou de bem-estar social. No primeiro caso, entende-se que a fonte normal de satisfação das necessidades é o mercado e que os indivíduos acedem a ele mediante os rendimentos obtidos pelo trabalho. No segundo, entende-se que no pacto social fundador da democracia a sociedade civil delega no Estado importantes funções de provisão social pautadas pelo universalismo e por um certo nível de redistribuição social da riqueza para que todos possam viver com um mínimo de dignidade.

Deste ponto de vista, o Estado português, à luz da Constituição da República, tem um mandato de tipo social-democrático (cfr. arts $1^{\circ}$ e $2^{\circ}$ da CRP e todo o Título II da mesma CRP sobre "Direitos e Deveres Económicos, Sociais e Culturais"). Porém, à luz da prática política e governativa que se instaurou quase desde a entrada em vigor da Constituição, é duvidoso que a extensão e a intensidade da acção do Estado correspondam a esse modelo. É que, apesar de a norma constitucional parecer configurar verdadeiros direitos subjectivos 
públicos à ajuda do Estado (Canotilho e Moreira, 2007: 814), a verdade é que o legislador ordinário tem tido um entendimento muito estrito acerca do que aos poderes públicos cabe garantir e uma boa parte dos preceitos constitucionais náo passam de meras normas programáticas sem conteúdo plasmado em legislação social de tipo universalista.

E isto tem a ver com o carácter recente do providencialismo estatal e com uma deficiente cultura de cidadania social entre nós - o que, aliás, é comum a outros países. Assim, quando se comparam as políticas sociais dos países do Sul da Europa, as semelhanças entre elas nestes domínios são flagrantes e apontam para o que já se tem designado de "síndrome do sul", caracterizado pela falta de determinação (sofness) do Estado, pelo pluralismo assistencial, pelos particularismos e clientelismo institucional, pela promiscuidade público-privado, pelo peso da doutrina social da Igreja, etc. (Leibfried e Pierson, 1992; Ferrera, 1996; Rhodes, 1996).

Autores como Esping-Andersen (1990) chamaram a nossa atenção para o facto de em nenhuma parte o Estado assumir isolado a satisfação das necessidades sociais básicas dos cidadão. A responsabilidade do Estado antes se combina, em diferentes proporçôes, com a responsabilidade da família e das instituiçóes da sociedade civil. $\mathrm{O}$ mercado rege-se por regras económicas que não asseguram a produção de bens e serviços sociais a preço acessível a toda população e, por isso, o Estado e as instituições da sociedade civil, incluindo as redes primárias de solidariedade baseadas no parentesco, na vizinhança e na amizade, são chamados a intervir em modalidades e com uma participação muito diversa.

O que importa reconhecer, no caso português (tal como na generalidade dos países do sul da Europa), é que a história de intervenção do Estado neste domínio específico dos cuidados aos cidadãos dependentes é muito recente, rompendo com a tradição de caber às familias e às comunidades (no caso destas, às organizações formais de solidariedade misericórdias, centros paroquiais, associações cívicas, etc) a obrigação de cuidar dos seus membros dependentes (Hespanha et al. 2000). Até agora, esta responsabilidade assumida pela própria "sociedade-providência" tem poupado ao Estado desempenhar o papel que os preceitos constitucionais lhe conferem neste domínio (tal como em vários outros). Contudo, a alteração progressiva e irreversível das condiçóes (família extensa, reduzida esperança de vida, divisão sexual do trabalho, fraca mobilidade, etc.) de que as famílias e as comunidades dispunham para cuidar dos seus veio a tornar dramática e insuportável a situação de abandono dos cidadãos dependentes ou a situação de sobrecarga dos familiares que cuidam desses cidadãos (Hespanha e Portugal, 2002).

Por isso o problema entra estridente na agenda política e obriga os governos a agir. Esta assunção da responsabilidade do Estado náo implica necessariamente que seja o Estado a prestar directamente os cuidados necessários através de instituiçóes próprias, tal como acontecera nos exemplos históricos de sociedades que construiram um Estado-Providência de tipo social-democrático. A existência de inúmeras instituições de solidariedade social, disseminadas pelo território, torna possível contratualizar a prestação dos cuidados com essas instituiçóes assumindo o Estado o papel de mero coordenador, fiscalizador ou regulador $^{2}$. Neste modelo torna-se essencial avaliar o modo como o Estado e as instituiçốes desempenham os seus papéis e a capacidade de resposta do próprio modelo.

\footnotetext{
2 Segundo a CRP ( $\operatorname{art}^{\circ}$ 63.5) ao Estado cabe apoiar e fiscalizar a actividade e funcionamento das instituiçóes particulares de solidariedade social ou outras, com vista à realizaçáo dos objectivos do $\operatorname{art}^{\circ}$ 67.2. ou seja, "promover a criação e garantir o acesso a uma rede nacional (..) de equipamentos sociais de apoio à família” (arto 67.2.b).
} 
Quanto ao segundo aspecto - modos de financiar a protecção social - também os Estados seguem diferentes sistemas. Os dois principais sistemas mais usados são o do financiamento através dos impostos e o do financiamento através das contribuiçóes dos trabalhadores para o seguro obrigatório. No primeiro caso, todos os cidadãos contribuintes pagam; no segundo apenas os cidadãos que trabalham pagam para o sistema. Mas existem outros efeitos que decorrem da diferente filosofia dos sistemas. O sistema de financiamento através dos impostos permite ao Estado afectar as receitas de acordo com as prioridades nacionais, permitindo inclusive corrigir algumas distorções decorrentes da desigual distribuição da riqueza na sociedade. Já o sistema de financiamento pelas contribuições limita a função redistributiva das políticas, tornando a protecção que cada cidadão recebe directamente dependente dos montantes por si descontados. Por isso este sistema tem sido qualificado de corporativo, ou seja, cada grupo profissional tem o seu regime próprio de protecção. Porém, o financiamento não se esgota nestas duas fontes. Em muitos casos, o acesso aos bens e serviços depende do pagamento de uma contrapartida financeira por parte do utilizador. Aqui podemos encontrar as situaçóes mais diversas: desde as taxas moderadoras que se destinam apenas a desincentivar a procura banal de serviços, até às taxas de utilização de serviços que correspondem a um pagamento dos custos estimados do serviço recebido ${ }^{3}$. Em sociedades de menores recursos com a portuguesa, a tentação dos governos é de introduzir sistemas de retribuição dos custos dos serviços eventualmente modelada pelos rendimentos dos cidadãos utentes, o que na linguagem de Esping-Andersen corresponde a um processo de re-mercadorização oposto ao de processo de desmercadorização que caracterizou os Estados-Providência social-democráticos.

O terceiro aspecto a reter é o do universo das pessoas abrangidas pelas políticas de protecção social. Aqui, existem dois sistemas polares: o sistema assistencialista que reserva apenas a protecção para aquelas pessoas que não tenham recursos suficientes, através de um regime de prova de insuficiência meios; e, no outro extremo, o sistema universalista que generaliza a protecção a toda a população que necessite de protecção, independentemente dos seus recursos. Em termos dos regimes de welfare tipificados por Esping-Andersen, o Estado-Providência social-democrático corresponde à filosofia universalista, enquanto que o Estado-Providência liberal corresponde à filosofia assistencialista. A tendência das reformas do Estado-Providência nas últimas décadas tem ido no sentido da redução da filosofia universalista, tendo as políticas passado a orientar-se preferencialmente para certos grupos-alvo da população (targeting) ou então é introduzido o princípio da discriminação positiva, dando preferência a quem tem menores rendimentos (princípio da selectividade). Os argumentos mais fortes contra esta selectividade invocam o carácter potencialmente estigmatizador das políticas dirigidas exclusivamente a pessoas de menos recursos ${ }^{4}$ e a perda de qualidade e residualização desses serviços dada a menor capacidade reinvindicativa dos seus utilizadores.

\footnotetext{
${ }^{3}$ Como não funcionam as regras de mercado para a formação dos preços, os custos têm de ser estimados e, tradicionalmente, esses custos eram estimados de uma forma que os tornava bem mais baixos do que os preços de mercado para serviços equivalentes. Uma das diferenças notórias na estimativa dos custos dos serviços públicos foi a sua aproximação ao de uma avaliação analítica dos custos de produção dos bens de mercado.

4 Veja-se o argumento usado pelos defensores do "rendimento básico" ou "de cidadania" contra o modelo de "rendimento mínimo garantido" ou outro similar para pessoas muito pobres (van Parijs, 2000).
} 
Finalmente, os níveis de protecção social. Os níveis de protecção do Estado têm a ver, fundamentalmente, com dois factores: a filosofia mais liberal ou mais social-democrática do Estado-Providência e o nível de recursos financeiros para afectar às políticas sociais. Um razoável indicador de performance neste domínio é a percentagem do produto nacional afecta às políticas sociais. Em 2003 a percentagem do PIB dos 15 países membros da UE afecta à despesa social era de $28,3 \%$, variando entre os $33,5 \%$ da Suécia e os $24,3 \%$ de Portugal (EUROSTAT, 2006). O padrão de repartição da despesa entre as várias funçóes é bastante desigual e varia significativamente de país para país. Em 2003 esse padrão era o seguinte para os 15 e para Portugal: a) cuidados de saúde - UE15 28,4\%, Portugal 28,8\%; b) deficiência - UE15 7,9\%, Portugal 11,5\%; c) velhice - UE15 40,9\%, Portugal 39,3\%; d) sobrevivência - UE15 4,6\%, Portugal 6,9\%; e) família e criança - UE15 8,0\%, Portugal 6,5\%; f) desemprego - UE15 6,7\%, Portugal 5,5\%; g) alojamento - UE15 2,0\%, Portugal $0,0 \%$; e h) pobreza/exclusão social - UE15 1,5\%, Portugal 1,5\% (ibid.). É notória a concentração da despesa social nas pensóes (velhice, deficiência e sobrevivência) e nos cuidados de saúde e, em particular em Portugal, onde atingem os $86,5 \%$ da despesa social total.

\section{Os cuidados continuados em Portugal}

Para além do que já ficou dito acima sobre as particularidades do modelo social português - e que se torna relevante para apreciar os programas específicos como os dos cuidados continuados -, convém ter igualmente em conta que o curso das políticas sociais e das reformas parece estar a ser influenciado, em grande medida, pelos padrôes de decisão política da União Europeia e por certos programas sociais adoptados por vários países membros que se tornaram modelares 5 .

A condição europeia de Portugal influenciou ainda as nossas políticas sociais por outras formas dignas de consideração. Primeiro, pela via dos fundos estruturais (principalmente do FSE) e de coesão (Programas Delors I e II), os quais se tornaram decisivos para o lançamento de programas em muitas áreas do social (emprego, formação profissional, saúde, educação, habitação e pobreza). Segundo, pela via do pacto de estabilidade e crescimento, associado ao sistema monetário europeu, que tornou o argumento da convergência em fundamento indiscutível para a retracção das políticas públicas, traduzida em cortes da despesa pública, no estrangulamento da segurança social, no congelamento dos salários e das prestaçōes sociais, na privatização, redução ou encerramento dos serviços publicos, tudo isto com consequências incontornáveis para o aumento da vulnerabilidade à exclusão e para o agravamento das desigualdades.

Portugal, tal como os outros países do sul da Europa, tem um sector de cuidados médicos e sociais continuados pouco desenvolvido. Trata-se de um domínio até há pouco tempo considerado da responsabilidade das famílias, mas que, mercê das mudanças ocorridas na estrutura e composição das famílias e da entrada massiva da população feminina no merca-

\footnotetext{
5 A Resolução do Conselho de Ministros no 59/2002 que cria o Programa Rede Mais para a protecção das pessoas com elevado grau de dependência (vd. infra) refere, a propósito, o papel do Comité de Protecção Social da Uniāo Europeia na definiçáo dos objectivos e na orientação e preparação das agendas do Conselho Europeu nesta matéria.
} 
do de trabalho, tem vindo a ser alvo da atenção crescente do Estado e das instituições não governamentais.

Um dos principais problemas que uma política de cuidados continuados tem de enfrentar é a da condição pobre da população dependente. Desde logo a dos idosos e, em particular, a dos idosos vivendo de uma pensão de reforma. De acordo com a informação estatística disponível, a condiçáo de reformado revela um risco de pobreza bastante mais elevado que o dos indivíduos que estâo a trabalhar, respectivamente $23 \%$ contra $11 \%$, em $2006^{6}$. Em 2001, a distribuição do rendimento monetário equivalente médio dos mesmos apresentava níveis inferiores aos da população portuguesa, ainda que se tenha sentido, entre 1995 e 2001, uma melhoria da situação monetária das pessoas idosas de mais baixos rendimentos e dos de classe média de rendimentos. Cerca de 66\% tinham rendimentos mensais inferiores à média nacional. Apesar da melhoria sustentada assegurada pelo sistema de segurança social, em particular, do sistema de pensóes, desde a segunda metade da década de 90, prevalecem situaçóes extremamente vulneráveis de idosos que vivem de pensóes com valores muito baixos (PNAI, 2006: 12). Então a pressão para que estes casos de dependência sejam suportados pelo sistema é muito forte e crescente, na medida em que o acesso ao mercado de cuidados esbarra com preços proibitivos e que a família cada vez menos dispóe de condiçôes para o acolhimento ${ }^{7}$.

Os apoios públicos de carácter assistencial em Portugal sempre tiveram um carácter esporádico e destinaram-se a resolver as dificuldades mais dramáticas. $\mathrm{O}$ único apoio assinalável para os casos em que a família não dispunha de meios para sobreviver tinha origem nas organizações da sociedade civil, em particular as de cunho confessional, mas importa reconhecer que esse apoio raramente tinha consistência, cobertura adequada ou qualidade técnica.

Por isso, a história dos cuidados continuados às pessoas dependentes não regista nenhum papel relevante do Estado ou das instituiçóes públicas. As poucas iniciativas institucionais que podem ser mencionadas cabem sobretudo às instituiçóes da Igreja e, dentre estas, às misericórdias. Nos últimos cem anos os apoios públicos de carácter assistencial - esporádicos e para resolver dificuldades pontuais mais dramáticas - eram concedidos directamente às famílias sem qualquer garantia de continuidade (Hespanha, 1998; Rodrigues, 1999).

O programa da Rede Nacional de Cuidados Continuados Integrados criado em 2006 vem preencher essa lacuna do sistema de protecção social português. Ele surge com a progressiva consciencialização da impotência dos dependentes e suas famílias, da falta de resposta das instituçóes da sociedade civil e da existência de uma pressão crescente sobre o Estado para que responda aos problemas graves de dependência com medidas articuladas de apoios médicos e sociais.

\subsection{Antecedentes}

Esta consciência foi-se traduzindo, no último quartel do séc. XX, no surgimento de respostas pontuais ou pouco estruturadas tanto públicas quanto privadas solidárias, num

${ }^{6}$ A taxa de risco de pobreza sobe dramaticamente para os $40 \%$ quando se trata de um idoso vivendo sozinho (EUROSTAT, 2007).

7 A proporçáo de idosos maiores de 65 anos internados nas unidades da RNCCI era de 80,2\% ao fim do primeiro ano de funcionamento do Programa (RNCCI, 2007:19). 
processo misto de desenvolvimento do Estado-Providência e de multiplicação e diversificação das organizaçôes não governamentais quase sempre sob a égide do Estado. Vale a pena esquissar a evolução dessas respostas de cuja experiência beneficiou o programa RNCCI.

A primeira referência vai para o Programa de Apoio Integrado a Idosos (PAII) criado em 1994 e que se destinava a ser promovido pelas organizaçóes não governamentais de base local ${ }^{8}$. Ele caracterizou-se por um conjunto de medidas inovadoras que visavam contribuir para a melhoria da qualidade de vida das pessoas idosas, prioritariamente no domicílio e no seu meio habitual de vida, desenvolvendo-se através de projectos de desenvolvimento central e a nível local.

De entre os objectivos do PAII incluiam-se: a promoção da autonomia das pessoas idosas e/ou pessoas com dependência, prioritariamente no seu meio habitual de vida; o estabelecimento de medidas para melhorar a mobilidade e acessibilidade a serviços; a implementação de respostas de apoio às famílias que prestem cuidados a pessoas com dependência, especialmente idosos; a promoção e apoio à formação de prestadores de cuidados informais e formais, de profissionais, familiares, voluntários e outras pessoas da comunidade; e o desenvolvimento de medidas preventivas do isolamento e da exclusão.

O Programa visava ainda contribuir para a solidariedade entre as geraçóes, para uma sociedade aberta a todas as idades, para o desenvolvimento de respostas inovadoras e integradas (no âmbito da saúde e da acção social), para a promoção de parcerias e para a criação de postos de trabalho.

A promoção das iniciativas devia ser assegurada pelas IPSS e Misericórdias e integrar as instituiçóes de saúde e da segurança social dos locais onde se desenvolviam os programas como parceiros activos. A gestão e monitorização dos projectos cabia a uma Comissão de Gestão, sedeada em Lisboa e o acompanhamento a nível local era realizado pelas mesmas instituiçóes que integravam a parceria responsável pela execução do projecto. Esta duplicidade de estatuto/funçóes veio a gerar constrangimentos e provocar um olhar pouco crítico sobre o andamento dos projectos. A própria cultura de parceria, não estando interiorizada, levou a que as pessoas não trabalhassem como parceiros mas sim como representantes das instituições.

Por seu turno, a cobertura territorial do Programa foi muito limitada e a continuidade no tempo não foi assegurada porquanto se tratava, quase sempre, de iniciativas experimentais. O financiamento para estes projectos durava em média dois anos, cessando depois a responsabilidade do Estado, o que tornou difícil às instituiçóes darem continuidade aos projectos e assegurarem a sua sustentabilidade financeira.

No entanto, estes Projectos foram importantes por terem permitido desenvolver acçôes inovadoras dirigidas à população idosa e, simultaneamente, por terem dinamizado parcerias locais. Algumas dessas acçóes representaram ganhos significativos para a populaçáo-alvo, como o alargamento do apoio domiciliário às vinte e quatro horas, incluindo os fins-de-semana, a melhoria da qualidade dos cuidados de saúde e de apoio social prestados, o apoio à formação das famílias, o investimento na criação de internamento temporário com reabilitação, a facilidade do acesso a ajudas técnicas, a melhor articulação com o pro-

8 Despacho Conjunto, de 1 de Julho de 1994, dos Ministros da Saúde e do Emprego e da Segurança Social e reiterado por despacho, em 4 de Julho de 1996, da Ministra da Saúde e do Ministro da Segurança Social e do Trabalho. 
cesso de preparação de altas hospitalares e institucionais e, ainda, o incentivo à eliminação de barreiras arquitectónicas nos domicílios das pessoas idosas abrangidas.

Em 1998, por iniciativa conjunta dos Ministérios da Saúde e do Trabalho e Solidariedade foram aprovadas orientaçóes gerais para regular a intervenção de uma forma articulada do apoio social e dos cuidados de saúde continuados dirigidos a pessoas em situação de dependência'. Dos diferentes tipos de respostas anunciadas, as mais procuradas foram as Unidades de Apoio Integrado (UAI) e o Apoio Domiciliário Integrado (ADI). Enquanto as UAI eram pensadas como algo surgindo das estruturas ou serviços já existentes (ou na sua proximidade), de pequena dimensão, em articulação com os serviços de saúde e de assistência social e em íntima ligação com as famílias, dando-lhes apoio e também formação, o ADI é pensado como a resposta prioritária e charneira, no sentido em que lhes cabe resolver as situações menos exigentes do ponto de vista da especialização dos cuidados e monitorizar as situações que possam evoluir para níveis de exigência mais elevados.

Umas e outras demonstraram ser possível um caminho de experimentação, no terreno, de formas organizativas de prestaçáo de cuidados continuados integrados e a experiência recolhida foi decisiva para fazer avançar uma política mais estruturada neste domínio.

Assim, em Fevereiro de 2002, foi publicada uma resolução do Governo que cria um sistema de Cuidados Continuados Integrados - designado Rede Mais ${ }^{10}$ - que viria a influenciar decisivamente o sistema actualmente em vigor. Considerando que a protecção social das pessoas com elevado grau de dependência constituia uma prioridade e devia ser tomada a cargo pelo Estado, este Programa visava instituir uma política de cuidados continuados integrados e criar uma rede de respostas organizadas de saúde e de apoio social integrando as duas dimensóes consideradas indissociáveis, a da solidariedade e segurança social e a da saúde.

O objectivo desta Rede era "garantir uma protecção social integrada, financeiramente sustentável, com base numa tipologia de respostas mais bem adaptadas às necessidades das pessoas em situação de dependência, ou em risco de nela entrarem, estruturada em redes locais que envolvam transversalmente estruturas públicas e privadas e que hão-de impulsionar a organização, a nível regional e nacional, de redes cada vez mais alargadas. Esta protecção social exige uma continuidade de cuidados em diferentes localizaçôes geográficas, assegurados por profissionais com formação diferenciada e ajustados aos problemas identificados, por forma a maximizar a sua eficiência e eficácia e a facilitar o respectivo acesso aos que deles necessitam”.

A queda do governo, pouco depois da aprovação do Programa Rede Mais e a constituição de um novo governo de coligação centro-direita vieram comprometer a execução deste Programa até ao mandato seguinte do Partido Socialista.

Entretanto, o XV Governo institui uma rede de cuidados continuados de saúde, através do Decreto-Lei n. ${ }^{\circ}$ 281/2003, de 8 de Novembro, que se aproxima da do governo socialista

9 Despacho Conjunto dos Ministros da Saúde e do Trabalho e da Solidariedade, número 407/98, de 15 de Maio,

10 Resolução do Conselho de Ministros n. ${ }^{\circ}$ 59/2002 revogada pelo artigo 30. ${ }^{\circ}$ do Decreto-Lei n. ${ }^{\circ}$ 60/2003 de 1 de Abril. 
mas que limita os cuidados ao campo da saúde (isto é, que não integra a segurança social) e coloca as instituiçóes de apoio social na dependência dos hospitais e centros de saúde ${ }^{11}$.

Regressado ao governo, o Partido Socialista recuperou o seu projecto anterior de cuidados continuados e integrados, incluindo expressamente no Programa de Governo de 2005 a criação de serviços comunitários de proximidade (SCP), a articulação de centros de saúde, hospitais e instituiçóes de apoio social para a prestaçáo de cuidados continuados, a reabilitação imediata do paciente crónico e idoso logo após o episódio agudo e sua reinserção na família, o planeamento dos equipamentos de cuidados continuados, a reactivação dos cuidados de saúde no domicílio e o reforço do apoio à família, através de internamentos temporários e prolongados, apoio domiciliário de saúde e recurso a call centers.

\subsection{A Rede Nacional de Cuidados Continuados Integrados ${ }^{12}$}

Este Programa visa a criação de uma rede de cuidados continuados, constituída por entidades públicas, sociais e privadas, nos domínios da saúde e da segurança social, destinada "a promover, restaurar e manter a qualidade de vida, o bem-estar e o conforto dos cidadãos necessitados dos mesmos em consequência de doença crónica ou degenerativa, ou por qualquer outra razão física ou psicológica susceptível de causar a sua limitação funcional ou dependência de outrem, incluindo o recurso a todos os meios técnicos e humanos adequados ao alívio da dor e do sofrimento, a minorar a angústia e a dignificar o período terminal da vida" (Decreto-Lei no 101/2006, de 6/6)

Para este Programa os cuidados continuados integrados definem-se como "o conjunto de intervençôes sequenciais de saúde e ou de apoio social, decorrente de avaliação conjunta, centrado na recuperação global entendida como o processo terapêutico e de apoio social, activo e contínuo, que visa promover a autonomia melhorando a funcionalidade da pessoa em situação de dependência, através da sua reabilitação, readaptação e reinserção familiar e social" ( $\left.\operatorname{art}^{\circ} 3^{\circ}, a\right)$. E a situação de dependência é definida como aquela "em que se encontra a pessoa que, por falta ou perda de autonomia física, psíquica ou intelectual, resultante ou agravada por doença crónica, demência orgânica, sequelas pós-traumáticas, deficiência, doença severa e ou incurável em fase avançada, ausência ou escassez de apoio familiar ou de outra natureza, não consegue, por si só, realizar as actividades da vida diária” ( $\left.\operatorname{art}^{\circ} 3^{\circ}, h\right)$ ).

O Programa define as situaçôes que têm acesso à Rede: $a$ ) dependência funcional transitória decorrente de processo de convalescença ou outro; $b$ ) dependência funcional prolongada; $c$ ) dependência de pessoas idosas com critérios de fragilidade; $d$ ) incapacidade grave, com forte impacte psicossocial; $e$ ) e doença severa, em fase avançada ou terminal ( $\left.\operatorname{art}^{\circ} 31^{\circ}\right)$.

A definição dos objectivos a atingir pelo sistema é muito ampla e engloba, a prestação de cuidados continuados de saúde e ou de apoio social a dependentes, de qualquer idade; cuidados terapêuticos e apoio social no domicílio destinado a pessoas com perda de funcionalidade ou em risco de a perder; progressiva cobertura a nível nacional, das necessidades das pessoas em situaçáo de dependência em matéria de cuidados continuados integrados e de cuidados paliativos, apoio aos familiares ou prestadores informais, na respectiva qua-

11 "O acesso à rede é determinado pelo hospital onde o utilizador se encontra internado ou pelo centro de saúde da sua área geográfica” ( $\left.\operatorname{art}^{\circ} 8^{\circ}, 1\right)$.

12 Cfr. o site desta Rede em http://www.rncci.min-saude.pt/RNCCI/. 
lificação e na prestação dos cuidados; articulação e coordenação em rede dos cuidados em diferentes serviços, sectores e níveis de diferenciação.

Do ponto de vista orgânico, a Rede situa-se a um nível intermédio de cuidados de saúde e de apoio social, entre os de base comunitária e os de internamento hospitalar. E do ponto de vista funcional, ela assenta numa tipologia de serviços constituida por quatro categorias: 1. as Unidades de Internamento (compreendendo Unidades de Convalescença UC, Unidades de Média Duração e Reabilitação - UMDR, Unidades de Longa Duração e Manutenção - ULDM, e Unidades de Cuidados Paliativos - UCP), 2. as Unidades de Ambulatório, correspondentes a Unidades de Dia e de Promoção da Autonomia Psicossocial, por situaçáo clínica decorrente de recuperação, 3. as Equipas Hospitalares (compreendendo as de Equipas de Gestão de Altas e as Equipas Intra-hospitalares de Suporte em Cuidados Paliativos) e 4. as Equipas Domiciliárias (compreendendo as Equipas de Cuidados Continuados Integrados e as Equipas Comunitárias de Suporte em Cuidados Paliativos).

Esta amplitude elevada de objectivos não se traduz na oferta imediata de serviços correspondentes mas sim na construção progressiva de um sistema nacional de cuidados que lhes possa dar resposta no futuro ( $\left.\operatorname{art}^{\circ} 4,2, \mathrm{~g}\right)$ ) e que se estima esteja implantado plenamente em 2016. Devida à opção pela complementaridade do papel do Estado, a edificação e consolidação do sistema fica dependente, entre outros factores, da disponibilidade de recursos, da articulação das respostas públicas e do dinamismo da sociedade civil. O programa teve um primeiro período inicial de um ano de carácter experimental em que se investiu principalmente nas unidades de internamento, através da contratualização de respostas com o sector privado não lucrativo (maxime, Misericórdias e Instituições Particulares de Solidariedade Social $)^{13}$

Se bem que o Programa vise a resposta às situaçóes mais dramáticas de dependência, a verdade é que este objectivo se combina com outros objectivos de natureza distinta. O mais óbvio é o do descongestionamento das unidades hospitalares de casos que exigem cuidados pouco diferenciados e tem a ver sobretudo com objectivos de gestáo económica dos recursos ${ }^{14}$. Em muitas situaçôes as altas hospitalares são adiadas pelo reconhecimento da incapacidade de os doentes e as suas familias suportarem os cuidados continuados após a alta hospitalar. Esta é a situação que manifestamente justifica a criação de unidades de convalescença, mas o mesmo motivo pode estar presente na criação das restantes unidades de internamento previstas pelo Programa. Em que medida os dois objectivos se conjugam ou conflituam é uma questão empírica que só poderá ser respondida a partir da experiência de execução do Programa. A situação crítica será aquela em que o doente permanece internado no hospital não apresentando justificaçáo clínica para isso, mas apenas social: o facto de não ter condiçóes para ser cuidado no domicílio. Do ponto de vista do hospital este internamento implica uma despesa evitável e ocupa uma cama que pode ser necessária para

13 No termo do período experimental, as taxas de cobertura por referência à população com idade igual ou superior a 65 anos era ainda muito baixa: de 20 camas por 100.000 habitantes para as UC, de 14 camas por 100.000 habitantes para as UMDR, de 40 camas por 100.000 habitantes para as ULDM e de 1 cama por 100.000 habitantes para as UCP (RNCCI, 2007). As metas para 2016, altura em que o Programa fica plenamente executado, são respectivamente 144/100.000 (UC); 160/100.00 (UMDR); 400/100.000 (ULDM) e 48/100.000 (UCP) (RNCCI, 2006).

14 No período experimental, mais de dois terços dos doentes internados em unidades do RNCCI eram provenientes de hospitais (RNCCI, 2007:19). 
outro doente. As unidades de internamento de longa duração serão porventura aquelas mais procuradas nestes casos.

Uma análise crítica do Programa obriga a salientar quatro aspectos que lhe dão especificidade e que, ao mesmo tempo, suscitam particulares problemas ao seu desenvolvimento: primeiro, trata-se de uma parceria entre o Estado e as instituiçôes e não de um serviço criado e mantido exclusivamente pelo Estado; segundo, sendo uma rede institucional de parceiros, a soluçáo encontrada defronta-se com problemas de governaçáo muito particulares; terceiro, abrange cuidados de saúde a par de cuidados sociais; quarto, a família constitui um dos elementos chave deste sistema.

Analisemos, em maior detalhe, estes quatro aspectos.

\section{1. um sistema público baseado em parcerias}

A rede de parceiros é vasta e integra entidades públicas (hospitais, centros de saúde, serviços locais e distritais da segurança social), instituiçóes privadas de solidariedade social (misericórdias, IPSS e pessoas colectivas de utilidade pública administrativa) e autarquias locais e, do ponto de vista organizativo, opera a um plano regional e a um plano local $\left(\operatorname{art}^{\mathrm{o}} 2^{\circ}\right)$.

No entanto, a coordenação cabe a uma estrutura nacional dependente, nas suas competências e composição, dos dois ministros da tutela, cabendo-lhe genericamente "promover a articulaçáo com os parceiros que integram a Rede". Existe também coordenação aos níveis regional e local: coordenação regional a cargo de representantes das ARS e CDSS (ECR); coordenação local a cargo de equipas concelhias (ECL) formadas por representantes das mesmas instituiçôes públicas ${ }^{15}\left(\operatorname{art}^{\circ} 9^{\circ}\right)$. Porém esta coordenação aos níveis sub-nacionais é meramente consultiva, no sentido em que as ECR e as ECL não têm qualquer autonomia deliberativa. Nota comum e geral é a de as tarefas de coordenação caberem a representantes das instituiçốes públicas da saúde e da segurança social.

Do ponto de vista operacional, é a parceria a nível local (entre as instituições locais de saúde, de segurança social e outras comunitárias) quem cria a estrutura orgânica destinada a prestar cuidados continuados integrados, o "serviço comunitário de proximidade" (SCP), o qual deve integrar unidades de saúde familiares (USF) ${ }^{16}$.

Decisóes importantes, como a de fazer ingressar as pessoas na Rede, cabe em regra às equipas coordenadoras locais mediante proposta de diferentes entidades consoante as situaçôes de dependência.

- no caso de doentes internados nos hospitais que necessitem de acompanhamento após alta, a proposta cabe às equipas de gestão de altas ${ }^{17}$, sediadas em hospitais de agudos e constituídas, no mínimo, por um médico, um enfermeiro e um assistente social;

- no caso de cuidados paliativos, a proposta cabe às equipas intra-hospitalares de suporte em cuidados paliativos sediadas em hospitais de agudos e constituídas, no mínimo, por um médico, um enfermeiro e um psicólogo;

15 E, eventualmente, um representante da autarquia.

16 Enquanto as USF não existirem, o SCP é constituído pelo Centro de Saúde, pelos serviços locais de Segurança Social, pelas autarquias locais e por outros serviços públicos, sociais e privados de apoio comunitário que a ele aderirem $\left(\operatorname{art}^{\circ} 3^{\circ}\right.$, al. $\left.\left.\mathrm{n}\right)\right)$.

17 Em articulação com as equipas terapêuticas hospitalares, as equipas coordenadores da Rede e as equipas prestadoras de cuidados continuados integrados dos Centros de Saúde ( $\operatorname{art}^{\circ} 24^{\circ}$ ). 
- no caso de pessoas dependentes cuja situação náo requer internamento, a proposta cabe às equipas de cuidados continuados integrados da responsabilidade dos cuidados de saúde primários e das entidades de apoio social para a prestação de serviços domiciliários ${ }^{18}$.

Sabe-se como, em regra, tendem a existir problemas de cooperação interinstitucional no seio das parcerias: ou porque os parceiros têm falta de tradição em cooperar entre si ou porque estão dotados de poderes muito desiguais no contexto da sociedade local, ou por outras razóes (Sousa et al., 2007). Os parceiros com maior conhecimento ou implantação no meio, com mais prestígio ou com maior legitimidade social, dificilmente aceitam perder a margem de autonomia de que dispóem e tendem a dominar e a impor os seus interesses próprios. Mas existem outros obstáculos ao diálogo, negociação e tomada colectiva de decisôes: a desconfiança, a autocracia, a inflexibilidade e intolerância, o radicalismo e a busca do conflito em vez de busca do consenso.

No caso presente, dificuldades dos dois tipos podem advir. Por um lado, entre as instituiçóes públicas da saúde e da segurança social que, salvo num curto período de tempo ${ }^{19}$, sempre estiveram dependentes de ministérios distintos apesar da proximidade dos problemas que a cada uma compete resolver relativamente a certas categorias da populaçáo, como é o caso das pessoas idosas ou dependentes. Uma deficiente cultura de cooperação a par de uma arreigada autonomia de acção, um complexo e pouco claro sistema de repartição de responsabilidades (designadamente, financeiras) e um momento crítico de reestruturação dos serviços contribuem ou podem contribuir para limitar uma cooperação eficiente ${ }^{20}$. Por outro lado, entre estas instituiçóes públicas e as organizaçóes privadas de solidariedade social que compóem os serviços comunitários de proximidade, as dificuldades podem dever-se à diferente capacidade de decisão com que estão investidas e ao papel ambíguo - ao mesmo tempo de cooperação e de fiscalização - que desempenham as primeiras relativamente às segundas.

Há ainda que reconhecer que quando não se verificam os pressupostos básicos para a parceria, ou seja, uma adesão voluntária, uma consciência do papel positivo da rede de parceiros e uma capacidade de participação efectiva, os parceiros podem não se envolver como seria expectável. Por sua vez, as motivaçôes para a participação nem sempre são as pretendidas, nem as mais nobres. Não se pode esquecer que os parceiros têm diferentes interesses, diferentes objectivos institucionais, diferentes sistemas de responsabilização, diferentes valores e diferentes estilos de envolvimento (Sousa et al., 2007).

\section{2. uma rede institucional de âmbito nacional}

A opçáo pela criação de uma rede nacional de cuidados visa, segundo o legislador, promover a distribuição equitativa das respostas a nível territorial. Este objectivo resulta da avaliação das experiências anteriores de apoio do Estado a iniciativas locais de natureza

\footnotetext{
${ }^{18}$ Em articulação com o Centro de Saúde e a entidade que presta apoio social ( $\left.\operatorname{art}^{\circ} 27^{\circ}, 2\right)$.

19 Apenas no V Governo Constitucional (1979-80) a Saúde e a Segurança Social ficaram na dependência da mesma pasta governamental: o Ministério dos Assuntos Sociais.

${ }^{20}$ A repartição dos encargos do sistema no primeiro ano de funcionamento mostra que três quartos da despesa de funcionamento foram imputados à saúde e apenas um quarto à segurança social, sendo que destes últimos parte corresponde a pagamentos suportados pelos utentes com as tipologias MDR e LDM (RNCCI, 2007:10). Por sua vez, as despesas de investimento, cerca de duas vezes e meia superiores às de funcionamento, oneram apenas a saúde.
} 
privada solidária que, sendo muito positivas em termos das populaçóes servidas, colocavam problemas sérios de equidade relativamente a outras populaçóes igualmente carentes e não servidas de resposta. Esta disparidade tornou-se flagrante ao longo das décadas de 80 e 90 em que se multiplicaram os projectos locais de intervenção social neste e em outros domínios, muitos deles beneficiando de financiamento europeu e com carácter experimental, sem nenhuma preocupação ou possibilidade de generalização para fora dos seus limites territoriais. $\mathrm{Na}$ última década a percepçáo das "injustiças” geradas por projectos sociais de âmbito local levou a uma preocupação com a equidade territorial na provisão de serviços sociais. O Programa Rede Social, criado em 1996, sintetiza bem esta preocupação do Estado ao criar um sistema de racionalização e planeamento das acçóes a nível concelhio por forma a evitar lacunas gritantes de protecção e uniformizar critérios de oferta de serviços. Mais recentemente o mesmo Programa viu alargadas estas funçóes de coordenaçáo e planeamento a níveis supra-concelhios e teve de passar a ter em conta a coerência dos critérios concelhios com os objectivos nacionais de acção para a inclusão.

Esta opção por uma rede nacional de cuidados coordenada pelo Estado afastou um modelo alternativo seguido em outros países: o de confiar à iniciativa privada solidária a oferta de cuidados à escala local, limitando-se o Estado a regular os requisitos básicos de abrangência e qualidade a que terão de obedecer os serviços. A maior autonomia das instituições locais é vista, em muitas sociedades, como uma vantagem em termos de ajustamento às necessidades locais e de melhor integração dos serviços na comunidade, mas existe um pressuposto que no caso português pode limitar esta opção: o da fraca maturidade e sustentabilidade das instituiçôes locais. Onde estas instituiçóes sejam débeis e pouco activas, o risco de insucesso é muito elevado.

A opção por serviços de base comunitária é também uma decorrência da filosofia do sistema de protecção social e é frequente em países que seguem o modelo liberal, como é o caso dos Estados Unidos da América, ainda que nestes tenda a prevalecer o sistema de seguros de saúde privados com cobertura de doença continuada.

Uma outra dimensão desta mesma questão tem a ver com um conflito de obrigaçóes que pode ocorrer no seio das instituiçóes locais incluídas na RNCCI. A génese e a lógica de inserção local das instituiçốes torna compreensível que estas se possam determinar por princípios de preferência ou prioridade aos membros da comunidade na oferta de cuidados relativamente a pessoas de fora. Contudo, neste período de implantaçáo do sistema em que a cobertura territorial é ainda incompleta, a Rede obriga as instituiçóes cooperantes a acolher os cidadãos mais prioritários segundo critérios regionais (e até) nacionais e sem consideração da sua origem territorial ${ }^{21}$. Ora, tem havido muitas resistências por parte das instituiçóes em dar prioridade a pessoas de fora ou a prescindir da reserva de um número mínimo de camas para pessoas da terra que venham a precisar, mostrando que a lealdade à comunidade é muito forte mesmo quando confrontada com a lealdade devida ao Estado, representando aqui a comunidade nacional. Trata-se de uma questáo muito sensível que exige um tratamento muito ponderado, pois qualquer postura excessiva pode prejudicar a relação que as instituiçóes têm (ou devem ter) com as suas comunidades. Também, do

${ }^{21} \mathrm{Na}$ definição de princípios a que o sistema deve obedecer, inclui-se o da proximidade de cuidados, através da "potenciação de serviços comunitários de proximidade $\left(\operatorname{art}^{\circ} 6^{\circ}, \mathrm{d}\right)$ ). A formulação do programa Rede Mais era mais explícita quanto à necessidade de "manter o (...) utilizador, sempre que possível, dentro do seu enquadramento comunitário" $\left.\left(\operatorname{art}^{\circ} 4^{\circ}, \mathrm{d}\right)\right)$. 
ponto de vista do apoio familiar, a colocação de pessoas dependentes em instituiçóes de acolhimento longe da sua comunidade de origem levanta sérios problemas de que convém estar consciente e deve ser evitada ou reduzida a uma duração mínima. O financiamento de deslocaçóes regulares de familiares directos é, decerto, uma compensação justa mas é preciso assegurar que essa medida é efectivamente aplicada e que não fica sujeita a condicionamentos burocráticos insuportáveis ${ }^{22}$.

Finalmente, uma precisão quanto ao uso do conceito de rede. A RNCCI integra diferentes instituiçóes, públicas e privadas, colocadas em diferentes níveis territoriais, relacionando-se entre si de uma forma hierarquizada e cooperando para produzir um resultado comum: os serviços de cuidados continuados. De fora ficam os doentes, os seus familiares e os cuidadores informais, que são concebidos como os destinatários ou beneficiários dos serviços produzidos pela Rede. Tomando como boa a distinção que Lemieux introduziu entre redes e aparelhos (Lemieux, 2000), segundo a qual os aparelhos são agrupamentos de agentes sociais organizados especificamente para fins de regulação externa dos públicos e assentando na distinção entre a organização que produz serviços e o público a quem a produção se destina, então estamos perante uma realidade que deve ser classificada como aparelho e não como rede. As redes não têm um público, apenas membros (sejam indivíduos, sejam instituições) e o seu modo de funcionamento é a auto-regulação (Godbout, 2004: 79). Esta precisão é útil para evitar os equívocos que a denominação rede pode suscitar: desde logo a ocultação de características típicas dos aparelhos burocráticos como a hierarquia e a autoridade, a rigidez e a universalidade.

\section{3. um sistema integrado de saúde e segurança social}

A originalidade deste programa relativamente aos anteriores consiste, como já foi referido, na multidimensionalidade dos cuidados prestados aos cidadãos dependentes, desde o apoio médico ao apoio social. Por isso, houve o cuidado de envolver os Ministérios da Saúde e do Trabalho e Solidariedade Social numa parceria que permita articular e coordenar as acçóes dos dois sectores.

Até hoje a coordenação dos apoios aos idosos, fora do quadro deste programa, tem sido difícil de estabelecer. Os serviços de cuidados ao domicílio assegurados por profissionais do Serviço Nacional de Saúde (SNS) cobrem as necessidades em matéria de tratamentos médicos e de cuidados de enfermagem enquanto que as necessidades de outra natureza, tais como a ajuda domiciliária de limpeza e manutenção e de refeiçóes ou a ajuda nas compras e no lazer são atribuiçóes da segurança social que opera principalmente através de instituiçôes de solidariedade social cuja presença ao nível local está muito desigualmente repartida. $\mathrm{O}$ que resulta mais flagrante nestes apoios é a falta de articulação entre eles e a duplicação de encargos que muitas vezes poderia ser evitada se houvesse uma programação concertada das ajudas entre os prestadores.

Dada esta experiência, a interacção e a cooperação de profissionais de distintas disciplinas e sectores foram reconhecidas expressamente como uma exigência pelo Programa RNCCI cuja intervenção de terreno opera através de equipas multidisciplinares e do trabalho interdisciplinar. Outrossim a delimitação clara das competências e a construção de

22 Refira-se, a propósito, que nos casos de permanência em unidades de internamento de média e de longa duração o internado tem de suportar um custo relativo aos cuidados de apoio social (o custo dos tratamentos de saúde será assegurado pelo SNS) de acordo com a sua capacidade económica ou da sua família. 
uma linguagem comum facilitadora da comunicação são consideradas indispensáveis neste quadro e, talvez por isso, a coordenação do Programa tem procurado definir a missão dos diferentes profissionais que intervêm nos cuidados cntinuados. Assim, relativamente aos assistentes sociais clarifica-se as distintas missóes a desempenhar pelos da saúde e pelos da segurança social. Enquanto a missão dos primeiros foi descrita como a de "enfatizar a relevância e a centralidade dos factores psicossociais, enquanto determinantes ou favorecedores do tratamento, da reabilitação, da readaptaçáo e da reintegração dos doentes/ dependentes nos ambientes sociais" mais adequados, a dos segundos é suposto centrar-se principalmente, nas questôes da "alocação de recursos requeridos para a efectivação dos cuidados em contexto não hospitalar, providenciando o acesso a prestaçóes sociais, a colocação em equipamentos sociais de apoio ou na disponibilização de serviços a doentes e famílias" (RNCCI, 2006).

Significativamente o documento que especifica estas distintas competências dos assistentes sociais foi elaborado pela Direcção-Geral da Saúde e reserva para os profissionais da saúde um conjunto alargado e exigente de atribuiçóes, nomeadamente no âmbito da dinamização e mobilização das comunidades locais ("O assistente social como capacitador de populaçóes e organizador de comunidades." ${ }^{23}$, que não valoriza a experiência e o conhecimentos próprios dos profissionais dos Centros Distritais de Segurança Social que trabalham nas comunidades. O mesmo se diga do não envolvimento das Redes Sociais concelhias ou, pelo menos, a náo consideração expressa dos documentos de diagnóstico e planeamento social por ela produzidos sobre os problemas sociais de cada concelho, incluindo os problemas de saúde.

\section{4. as famílias e a comunidade como elementos chave do sistema}

Nestas parcerias para a prestação de cuidados, os parceiros são organizações dominadas pelo seu corpo técnico ou representadas por um voluntariado solidário que não incorpora mecanismos de participação dos cidadãos, nomeadamente daqueles que a sua acção visa beneficiar.

E no entanto, tratando-se de uma intervenção que se propóe, em grande medida, substituir os cuidados informais de carácter familiar devia ser colocado um grande cuidado na participação das famílias dos utentes e das comunidades locais, pois são elas que constituem o contexto social de vida dos cidadãos utentes. Mesmo que os parceiros institucionais queiram assumir esse papel em nome destes cidadãos, é fácil de reconhecer que eles não têm legitimidade para representar os assistidos, designadamente nos momentos-chave do diagnóstico e planeamento da intervenção, porque não foram escolhidos por estes.

Na concepção do Programa de cuidados continuados, a família e a comunidade são vistos mais como um recurso do sistema do que como detentores de verdadeiros poderes de participação. Mais, espera-se delas que cooperem com o sistema com vista a aliviá-lo o mais possível do encargo de cuidar dos dependentes. Esta ideia transparecia claramente do

23 A organização comunitária é considerada nesse documento como uma dimensão nuclear do desempenho do assistente social da saúde e visa "a satisfação de necessidades dos cidadãos em prestação de cuidados ou serviços. Uso de metodologias de intervenção que visam o reforço ou o desenvolvimento do poder organizativo das populaçōes na satisfação das suas necessidades e prevêem a articulação e/ou cooperação entre recursos (públicos; privados lucrativos ou não lucrativos; formais ou informais), tendo em vista a prestação dos cuidados e dos serviços de proximidade necessários ao maior bem estar, autonomia e inserção social ou sócio-profissional dos doentes/dependentes" (RNCCI, 2006). 
preâmbulo do Decreto-Lei n. ${ }^{o}$ 281/2003, de 8 de Novembro. Depois de reconhecer que "na prestação de cuidados de saúde em geral a família e a comunidade social têm constituído (...) factores essenciais e indispensáveis no apoio aos seus concidadãos, nomeadamente aos mais frágeis e carenciados", afirma-se que "a sua iniciativa e acção são fundamentais, não apenas para evitar o prolongamento de estadas em regime de internamento por razóes alheias ao estado de saúde, como também para a reabilitação global e a independência funcional dos doentes, o apoio domiciliário e ocupacional de que necessitam e a reinserção social a que têm direito". Finalmente, na definição dos princípios a que o sistema deve obedecer, a família é reconhecida "como elemento determinante da relação humanizada, constituindo o suporte e lugar privilegiado para a pessoa carenciada" ( $\operatorname{art}^{\circ} 4^{\circ}, a l$. a). Ou seja, a família é vista sempre como um sujeito de responsabilidades sociais em vez de ser considerada na sua dimensão de co-actor público, sujeito activo de uma nova política de cuidados (Fontes e Martins, 2006: 37).

E, no entanto, faz todo o sentido integrar as famílias e as comunidades o mais possível neste processo de cuidados. É certo que em Portugal, não existe uma tradição de community care ou de saúde colectiva que desenvolva formas associativas de promoçáo de cuidados de saúde ou simples acçôes colectivas de defesa de interesses dos cidadãos e das famílias com problemas de saúde. Nem a saúde pública, nem a clínica geral/medicina familiar assumiram esse papel ou fomentaram a organização da comunidade em torno de objectivos de defesa e promoção da saúde: a saúde pública porque se tem confinado cada vez mais a uma intervenção do tipo sanitarista e a medicina familiar porque nunca soube passar do âmbito da família para o âmbito mais alargado da comunidade, ainda que tenha o grande mérito de ter compreendido a importância de reconhecer a interdependência existente entre os problemas de saúde individuais e o contexto familiar que os envolve.

Hoje conhece-se pouco das necessidades locais em saúde e, ainda menos, das preferências e expectativas da população. Contrariamente a outros domínios, como o das necessidades sociais básicas ${ }^{24}$ ou da educação, não existem na saúde programas de diagnóstico, planeamento ou coordenação da intervenção à escala local que permitam contrariar a orientação marcadamente individualista do nosso sistema de cuidados de saúde e assegurar aos cidadãos a oportunidade de exprimirem as suas preferências e as suas expectativas relativamente ao problema.

A participaçáo da comunidade a que nos referimos é muito mais do que a participação das famílias segundo as formas que foram previstas no Programa da RNCCI. Recorde-se que estas são chamadas a participar na elaboração dos "planos individuais de intervenção", ou seja, o conjunto dos objectivos a atingir com os cuidados continuados em cada caso face às necessidades identificadas; e ainda no encaminhamento dos doentes para as unidades e equipas da Rede ( $\operatorname{art}^{\circ} 6^{\circ}$, al.h). Num sentido mais positivo, mas de alguma forma não expresso na legislação, vai a preocupação, já assinalada anteriormente, de que os técnicos

${ }^{24}$ O Programa Rede Social, criado em 1997, instituiu um sistema permanente de recolha de informação social, de diagnóstico e planeamento da acção das instituiçóes locais e de coordenação da intervenção à escala dos concelhos e das freguesias. Também o Programa dos Territórios Educativos de Intervenção Prioritária (criado pelo Despacho n. ${ }^{\circ}$ 147-B/ME/96, de 8 de Julho de 1996) visa garantir as condiçôes para o sucesso educativo de todos os alunos de um determinado território, especialmente daqueles que se encontram em situaçóes de risco de exclusão social e escolar. As escolas integrantes de um território educativo elaboram projectos educativos, com a intervenção de vários parceiros, designadamente professores, alunos pessoal não docente, associaçốes de pais, autarquias locais, associaçóes culturais e associaçóes recreativas. 
sociais possam servir de agente animador, mobilizador e mesmo de provedor das comunidades a que as pessoas dependentes pertencem. Para que isso seja possível, muito terá de mudar nas práticas dos técnicos de saúde, na filosofia de intervenção dos serviços de saúde e na cultura profissional dos assistentes sociais.

\section{Conclusão}

$\mathrm{O}$ caso analisado ilustra eloquentemente as novas metodologias de intervenção que o Estado-Providência está a desenvolver nesta sua nova fase de evolução. De uma forma sintética, a nova geração de políticas sociais privilegia a actuação do Estado em parceria com organizaçóes da sociedade civil, a descentralização do desenho das medidas de política e a sua gestão partilhada pelas instituiçóes locais, a co-responsabilização do prestador e do beneficiário na aplicação das medidas, o efeito de proximidade em vez da solicitude distante, a flexibilidade das acçóes em vez da tipificação das valências. Pautando-se por princípios de eficácia e de cidadania, há que reconhecer que as políticas sociais são hoje mais exigentes na sua aplicação e também mais vulneráveis a distorçóes.

Dentre as metodologias usadas, a das redes institucionais tornou-se uma das mais correntes e de legitimidade mais amplamente reconhecida precisamente porque o parceiros da rede parecem partilhar do governo das políticas. E, contudo, a condição destas redes de parceiros não corresponde exactamente ao modelo das parcerias tradicionais da sociedade civil em que a adesão é negociada e produto de um cálculo estratégico por parte dos parceiros, em que os objectivos não estáo previamente fixados e em que não existem relaçóes burocráticas de autoridade e hierarquia entre os parceiros. No caso da RNCCI alguns parceiros (saúde e segurança social) estão vinculados ao mesmo programa de governo e relacionam-se entre si como agentes de um mesmo corpo, outros parceiros (órgãos da administração central e serviços desconcentrados) relacionam-se entre si de acordo com regras de hierarquia burocrática, outros ainda (serviços da segurança social e instituiçóes de solidariedade social) estão vinculados entre si por acordos de cooperação ou dispóem de um estatuto de utilidade pública atribuído pelo parceiro Estado). A atipicidade desta rede relativamente ao protótipo das redes sociais levaria a qualificá-la antes de aparelho burocrático (Lemieux) ou de partenariado (Rodrigues e Stoer, 1998).

Seja como for, o efeito simbólico que o uso da expressão rede confere ao próprio Programa obrigou-nos a questionar alguns aspectos que podem vir a tornar-se problemáticos no seu desenvolvimento. Primeiro, o de uma parceria que não resulta de um pacto antes funciona como um instrumento para agilizar a realização de objectivos pré-definidos. Segundo, o de uma implantação territorial de âmbito nacional que dá pouco espaço a fórmulas de auto-organização local e não inova suficientemente em relação ao sistema de administração centralizada tradicional no nosso país. A aparente descentralização das decisóes faz-se num quadro normativo bastante rígido, em termos de modalidades de intervenção, tipologia de utilizadores e regimes de financiamento. Terceiro, um sistema integrado de respostas que não leva tão longe quanto deveria a incorporação de competências e de experiências sectoriais distintas. A composição das equipas ainda é dominada pela perspectiva dos cuidados continuados como um problema fundamentalmente do âmbito da saúde, quando se sabe que, nas práticas de cuidados informais, as redes de parentesco, amizade e vizinhança ou seja, o capital social local, constituem a principal fonte de apoio e protecção. Finalmente, 
o papel deixado à família e à comunidade parece ser muito limitado e corresponder a uma ideia (tradicional) de que os grupos primários partilham a responsabilidade de cuidar dos seus dependentes e de que tudo o que se lhes exige é que colaborem com o Programa para este poder desempenhar a sua missão. É certo que alguns documentos que aprofundam o Programa defendem uma perspectiva mais avançada quanto à participação das famílias e de comunidade e à sua autonomia para propor e organizar respostas mais adequadas, mas a tradução disso na legislação é por enquanto nula. Resta saber como as coisas se vão passar no terreno...

\section{Referências bibliográficas}

CANOTILHO, José Joaquim Gomes; MOREIRA, Vital - Constituição da República Portuguesa. Anotada. Coimbra: Coimbra Editora, 2007.

EC - Modernising social protection for the development of high-quality, accessible and sustainable health care and long-term care: support for the national strategies using the "Open Method of Co-ordination", COM (2004) 304 final, 2004.

EC - Modernising social protection for the development of high-quality, accessible and sustainable health care and the long-term care: support for the national strategies using the "open method of coordination" Brussels, 20.4.2004 COM (2004) 304 final, 2004.

ESPING-ANDERSEN, Gosta - Three Worlds of Welfare Capitalism. Princeton: Princeton University Press, 1990.

EUROSTAT - Social Protection Expenditure and Receipts. Data 1995-2003. Luxembourg: Office for Official Publications of the European Communities, 2006.

EUROSTAT - At-risk-of-poverty rate after social transfers, by age group. 2007. (http://epp.eurostat.ec.europa.eu/ portal/page?_pageid=1996,39140985\&_dad=portal\&_schema=PORTAL\&screen=detailref\&language $=$ en $\&$ pr oduct=sdi_ps\&root=sdi_ps/sdi_ps/sdi_ps_mon/sdi_ps1112)

FERRERA, Maurizio - "The Southern Model of Welfare in Social Europe". Journal of European Social Policy. 6/1, 1996, pp. 17-37.

FONTES, Breno; MARTINS, Paulo - Redes, Práticas Associativas e Gestão Pública. Recife: UFPE, 2006.

GODBOUT, Jacques - "Digressão sobre as redes e os aparelhos". In Martins, Paulo Henrique, Fontes, Breno (orgs.) Redes Sociais e Saúde. Novas Possibilidades Teóricas. Recife: Editora Universitária UFPE, 2004.

HESPANHA, Pedro - "O lugar dos Actores Colectivos na Regulação Social: o caso das Instituiçóes Particulares de Solidariedade Social”. In SANTOS, Boaventura de Sousa et al., O Estado e Sociedade Civil: a criação de actores sociais num periodo de reconstituição do Estado. Relatório de Investigação. Coimbra: Centro de Estudos Sociais, 1998.

HESPANHA, Pedro et al. - Entre o Estado e o Mercado. As fragilidades das Instituiçôes de Protecção Social em Portugal. Coimbra: Quarteto, 2000.

HESPANHA, Pedro; PORTUGAL, Sílvia - A Transformação da Família e a Regressão da Sociedade-Providência. Porto: Comissão de Coordenação da Regiâo Norte, 2002.

LEIBFrIED, S; PIERSON, P. - "Prospects for a Social Europe". Politics and Society. 20(3), 1992, pp. 367-375.

LEMIEUX, Vincent - À Quoi Servent les Réseaux Sociaux? Sainte-Foy: IQRC, 2000.

OECD - Long Term Care for Older People. Paris: OECD, 2005.

PNAI - Plano Nacional de Acção Para Inclusão. Portugal 2006-2008. Lisboa: Ministério do Trabalho e da Solidariedade Social, 2006.

RHODES, Martin - "Southern European Welfare States: Identity, Problems and Prospects for Reform". South European Society and Politics - Special Issue on Southern European Welfare States. vol.1, no 3, 1996, pp. 1-22.

RNCCI - Manual de Boas Práticas para os Assistentes Sociais da Saúde na Rede Nacional de Cuidados Continuados Integrados. RNCCI, 2006. (http://www.rncci.min-saude.pt/NR/rdonlyres/DE3DCDED-B8C2-4E56-86B966761CCF3B73/7177/ManualBoasPraticasASSRNCCI.pdf)

RNCCI - Relatório de Monitorização da Implementação das Experiências Piloto da Rede Nacional de Cuidados Continuados Integrados. Lisboa: Cuidados Integrados, 2007.

RODRIGUES, Fernanda; STOER, Stephen - Entre Parceria e Partenariado. Oeiras, Celta, 1998.

RODRIGUES, Fernanda - Assistência Social e Politicas Sociais em Portugal. Lisboa: Ediçôes ISSS, 1999. 
SOUSA, Liliana; HESPANHA, Pedro; RODRIGUES, Sofia; GRILO, Patrícia - Famílias Pobres: Desafios à Intervenção Social. Lisboa: Climepsi Editores, 2007.

UEMO (www.uemo.org/history/a_challange_for_uemo_2002_htm)

Van PARIJS, Philippe - "Rendimento Básico: Rendimento Mínimo Garantido para o Século XXI?". In IDS, Actas do Seminário Políticas e Instrumentos de Combate à Pobreza na Uniāo Europeia. Almancil, 2000. tionand comparison of integrated care in six EU countries. Maarsen: Elsevier Gezondheidszorg, 2003. 